\title{
Environmental epidemiology in a crossfire
}

\author{
Ruth A. Etzel ${ }^{1}$, Philippe Grandjean ${ }^{2,3^{*}}$ and David M. Ozonoff ${ }^{4}$
}

\begin{abstract}
Two tendencies have emerged in environmental epidemiology that hamper the translation of research findings into prevention of environmental hazards. One is the increased focus on highlighting weaknesses of epidemiology research that is clearly meant to explain away the research conclusions and weaken their possible implications for interventions to control environmental hazards. Another is the voluminous amount of information sharing that involves a substantial amount of misinformation, as part of the ongoing infodemic. In this light, the appearance of the catalogue of doubt-raising strategies, indeed the worst practices of scientific inference, is good news. Collected under the auspices of the International Network for Epidemiology in Policy, it serves to illustrate the range of possible (and impossible) forms of critique that may be raised on behalf of vested interests or other groups who for some reason disagree with the epidemiological conclusions. We believe that this systematic list will be useful in our field and help to identify critiques of policy options that are hidden and sometimes suppressed in weighing the epidemiological evidence.
\end{abstract}

Keywords: Conflict of interest, Doubt, Environmental epidemiology, Infodemic, Policy, Public health, Research integrity

An unexpected consequence of the coronavirus disease (COVID-19) pandemic has been to thrust the science of epidemiology into the spotlight as public health experts struggle to devise policies to combat a threat still poorly understood. The best way to interpret the vast variety of freshly generated findings in a context of scanty information on virus behavior and evolution has confounded experts and laypersons alike, often complicated by the admixture of commercial and political factors that can perturb and/or distort interpretations. This Journal and environmental epidemiology in general are well acquainted with the problems, although they may be less publicly visible and often not appreciated by policy makers, the media and laypersons.

A principal method to deflect unwanted policy implications of properly conducted epidemiological studies is

\footnotetext{
* Correspondence: pgrand@sdu.dk

${ }^{2}$ Harvard T.H. Chan School of Public Health, Department of Environmental Health, Boston, MA 02115, USA

${ }^{3}$ Department of Public Health, University of Southern Denmark, Odense, Denmark

Full list of author information is available at the end of the article
}

to deliberately frame the results in a way that casts doubt and manufactures uncertainty about their validity $[1,2]$. We use the word "manufacture" to emphasize the recognizable techniques employed by special interests to accomplish this. We have previously covered various aspects of the problem in the Journal [3, 4], and we will continue to raise this issue because of its paramount importance to scientists, policy makers and the public. The article by Soskolne et al. just published in Environmental Health [5] amply illustrates the many approaches to generating doubt. Controversies about the interpretation of the research studies, as well as their policy implications, are being amplified by what the World Health Organization (WHO) has called an infodemic of distortion and untruths [6].

Thoughtful and constructive critique is a necessary part of science, of course. This Journal practices open peer review to facilitate the exchange of frank and transparent views and perspectives among colleagues in the field [7]. The openness is a recognition that where one stands often depends upon where one sits, as the cliché

(c) The Author(s). 2021 Open Access This article is licensed under a Creative Commons Attribution 4.0 International License, which permits use, sharing, adaptation, distribution and reproduction in any medium or format, as long as you give appropriate credit to the original author(s) and the source, provide a link to the Creative Commons licence, and indicate if changes were made. The images or other third party material in this article are included in the article's Creative Commons licence, unless indicated otherwise in a credit line to the material. If material is not included in the article's Creative Commons licence and your intended use is not permitted by statutory regulation or exceeds the permitted use, you will need to obtain permission directly from the copyright holder. To view a copy of this licence, visit http://creativecommons.org/licenses/by/4.0/ The Creative Commons Public Domain Dedication waiver (http://creativecommons.org/publicdomain/zero/1.0/) applies to the data made available in this article, unless otherwise stated in a credit line to the data. 
goes. The goal is to weed out purposefully distorted interpretations produced by financial or other sources of conflicting interests. The techniques employed can be subtle and hard to recognize. They often seem to appeal to science's best aspirations. For example, "sound science" and "evidence-based toxicology" have been employed to counter findings that have the potential to be troublesome to a well-resourced or situated special interest $[8,9]$. This approach has even taken the form of a call for "Good Epidemiological Practice" that originated with industry groups [10] whose apparent goal was to discredit evidence that was considered unwelcome.

For example, a frequent strategy has been to elevate Bradford Hill's well-known general viewpoints on features of causal associations to necessary and sufficient criteria, although the author never used the word "criterion," but referred to aspects and viewpoints, while emphasizing his nine "examinations" as useful "if available and applicable" [11]. Thus, the nine features should not be employed as a checklist, as causality cannot be established by satisfying a simple list of qualitative conditions [12-14]. Further, the aspects of causal associations are asymmetric: Although affirmative answers may support causality, none of them is a necessary condition (perhaps apart from the temporal relationship), and the lack of one or more affirmative answers does not speak against causation [15].

A consequence of these tactics, as described in the "Late lessons from early warnings" project of the European Environment Agency [16] and also highlighted in this Journal [4], many optimistic assumptions on supposedly innocuous chemicals were later found to be misleading and in fact dangerous to human health. That a chemical is innocuous unless scientific documentation has shown otherwise has been appropriately named the "untested chemical assumption" by a committee of the U.S. National Research Council [undefined].

The controversies are magnified by the ongoing infodemic that rapidly disseminates all kinds of health information along with half-truths through a variety of media and informational channels [6]. Because of concerns about misinformation and resulting chaos in relation to the COVID-19 pandemic, WHO has called for better management of online platforms and for building resilience to the distorting effects of misinformation. These recommendations follow a thorough report from a working group on how to end the infodemic [18], in which transparency and prevention of conflicts of interest feature prominently.

Unlike online social media platforms, scientific journals have not been identified as primary contributors to the infodemic associated with the coronavirus pandemic. Most journals, like the present one [7], comply with the guidelines of the Committee on Publication Ethics and require disclosure of potential conflicts of interest (https://publicationethics.org). Simple disclosure, however, is a necessary but not a sufficient step to resolve conflicts of interest. The International Network for Epidemiology in Policy (INEP) responded to this situation by releasing an extensive Position Statement on Conflict-of-Interest and Disclosure in Epidemiology (https://epidemiologyinpolicy.org/coi-d-positionstatement). Drawing from this source, a new Environmental Health article [5] expands on, explains, and provides literature references to each of 33 tactics, most of them from the initial version of the toolkit in the INEP statement. These items constitute methods/techniques, arguments, and other tactics commonly used to distort and misapply epidemiological science.

That management of conflicting interests in science may be threatened by vested interests is exemplified by a recent issue of the American Journal of Health Behavior on the use of electronic nicotine delivery devises among adults [19]. Every article in the issue was authored by scientists employed by JUUL (a manufacturer of electronic cigarettes) or authors hired as consultants to the tobacco industry. Peer review was reportedly conducted, but, in the absence of open peer review, the identity and affiliations of the peer reviewers are unknown. The special issue was released at a time where JUUL's application to continue sales is under consideration by the U.S. Food and Drug Administration. This incident suggests that the infodemic is also affecting scientific publication, as has also occurred in the past with, e.g., the food industry [20].

Consideration of study validity and scrutiny of scientific inference and conclusions are crucial for scientific journals, along with transparency and appropriate handling of potentially conflicting interests. The range of possible (and impossible) forms of critique that may be raised on behalf of vested interests or other groups who desire to blunt or obscure the thrust of the epidemiology conclusions is substantial [5]. The new toolkit may serve as a checklist of, or guide to key methodological issues, to identify whether epidemiology results are being or could be misinterpreted, and for use by those who seek better ways to teach critical review of the scientific literature. Although epidemiologists are often skillful "flaw catchers", this toolkit may be particularly valuable for training epidemiologists and other healthcare professionals on the ways in which epidemiology can be distorted. In this so-called post-truth era and with the advent of the infodemic, there is an increasingly urgent need for additional safeguards to protect research integrity.

Given the confusing claims on how to interpret epidemiology research, the article by Soskolne et al. [5] is 
particularly welcome in helping to sort out which are genuine uncertainties or conundrums and which are manufactured.

\section{Abbreviations}

COVID-19: Coronavirus disease 2019; INEP: International network for epidemiology in policy; WHO: World Health Organization

\section{Acknowledgments}

None

\section{Authors' contributions}

All authors contributed to the writing. All authors read and approved the final manuscript.

\section{Funding}

PG is supported by the NIEHS Superfund Research Program (P42ES027706).

\section{Declarations}

\section{Ethics approval and consent to participate}

(none)

\section{Competing interests}

All authors have editorial responsibilities for Environmental Health.

\section{Author details}

'Milken Institute School of Public Health, The George Washington University, D. C, Washington 20052, USA. ${ }^{2}$ Harvard T.H. Chan School of Public Health, Department of Environmental Health, Boston, MA 02115, USA. ${ }^{3}$ Department of Public Health, University of Southern Denmark, Odense, Denmark. ${ }^{4}$ Department of Environmental Health, Boston University School of Public Health, Boston, USA.

\section{Published online: 19 August 2021}

\section{References}

1. Michaels D. Doubt is their product: how industry's assault on science threatens your health. New York: Oxford University Press; 2008.

2. Michaels D. The triumph of doubt: dark money and the science of deception. New York: Oxford University Press; 2020.

3. Baur X, Soskolne CL, Bero LA. How can the integrity of occupational and environmental health research be maintained in the presence of conflicting interests? Environ Health. 2019;18(1):93. https://doi.org/10.1186/s12940-0190527-X.

4. Goldberg RF, Vandenberg LN. The science of spin: targeted strategies to manufacture doubt with detrimental effects on environmental and public health. Environ Health. 2021;20(1):33. https://doi.org/10.1186/s12940-02100723-0.

5. Soskolne CL, Kramer S, Ramos-Bonilla JP, Mandrioli D, Sass J, Gochfeld M, et al. Toolkit for detecting misused epidemiological methods. Environ Health. 2021;20. https://doi.org/10.1186/s12940-021-00771-6.

6. World Health Organization. Infodemic [https://www.who.int/health-topics/ infodemic].

7. Grandjean P, Ozonoff D. Environmental health: the first five years. Environ Health. 2007:6(1):27. https://doi.org/10.1186/1476-069X-6-27.

8. Blair A, Saracci R, Vineis P, Cocco P, Forastiere F, Grandjean P, et al. Epidemiology, public health, and the rhetoric of false positives. Environ Health Perspect. 2009;117(12):1809-13. https://doi.org/10.1289/ehp.0901194.

9. Rudén C, Hansson SO. Evidence-based toxicology: "sound science" in new disguise. Int J Occup Environ Health. 2008;14(4):299-306. https://doi.org/1 0.1179/oeh.2008.14.4.299.

10. Ong EK, Glantz SA. Constructing "sound science" and "good epidemiology": tobacco, lawyers, and public relations firms. Am J Public Health. 2001;91(11): 1749-57. https://doi.org/10.2105/AJPH.91.11.1749.

11. Hill AB. The environment and disease: association or causation? Proc $R$ Soc Med. 1965:58(5):295-300. https://doi.org/10.1177/003591576505800503.

12. Krieger N. Epidemiology and the web of causation: has anyone seen the spider? Soc Sci Med. 1994;39(7):887-903. https://doi.org/10.1016/0277-953 6(94)90202-X.
13. Kundi M. Causality and the interpretation of epidemiologic evidence. Environ Health Perspect. 2006;114(7):969-74. https://doi.org/10.1289/ehp.82 97.

14. Rothman KJ, Greenland S. Causation and causal inference in epidemiology. Am J Public Health. 2005;95(Suppl 1):S144-50. https://doi.org/10.2105/A JPH.2004.059204.

15. Neutra RR, Cranor CF, Gee D. The use and misuse of Bradford Hill in U.S. tort law. Jurimetrics. 2018;58(2):127-62.

16. European Environment Agency. Late lessons from early warnings: The precautionary principle 1896-2000. Environmental issue report № 22. Copenhagen; 2001. https://www.eea.europa.eu/publications/environmental issue_report_2001_22.

17. National Research Council. Science and decisions: Advancing risk assessment. Washington, D.C: National Academy Press; 2009.

18. Forum on Information \& Democracy. 250 recommendations on how to stop "infodemics" [https://informationdemocracy.org/2020/11/12/250recommendations-on-how-to-stop-infodemics/ ]

19. Kaplan S. JUUL is fighting to keep its e-cigarettes on the U.S. market. New York: New York Times; 2021. https://www.nytimes.com/2021/07/05/health/ juul-vaping-fda.html

20. Mialon M, Swinburn B, Sacks G. A proposed approach to systematically identify and monitor the corporate political activity of the food industry with respect to public health using publicly available information. Obes Rev. 2015;16(7):519-30. https://doi.org/10.1111/obr.12289.

\section{Publisher's Note}

Springer Nature remains neutral with regard to jurisdictional claims in published maps and institutional affiliations.
Ready to submit your research? Choose BMC and benefit from:

- fast, convenient online submission

- thorough peer review by experienced researchers in your field

- rapid publication on acceptance

- support for research data, including large and complex data types

- gold Open Access which fosters wider collaboration and increased citations

- maximum visibility for your research: over $100 \mathrm{M}$ website views per year

At BMC, research is always in progress.

Learn more biomedcentral.com/submissions 